\title{
DIVULGAÇÃO CIENTÍFICA E EDUCAÇÃO PATRIMONIAL EM ARQUEOLOGIA: A EXPERIÊNCIA DO I WORKSHOP DE ARQUEOLOGIA DA UNESC
}

\author{
Josiel Dos Santos ${ }^{1}$ \\ Diego Moser ${ }^{2}$ \\ Lucy Cristina Ostetto ${ }^{3}$ \\ Marcos Cesar Pereira Santos 4 \\ Juliano Bitencourt Campos ${ }^{5}$
}

\section{RESUMO}

Este artigo apresenta as atividades desenvolvidas durante o I Workshop de Arqueologia da UNESC, realizado no âmbito da VII Semana de Ciência e Tecnologia, durante os dias 17 e 21 de outubro de 2016. Além de uma exposição arqueológica, foram realizadas oficinas temáticas de confecção de réplicas de cerâmica arqueológica, de arte rupestre e de escavação arqueológica. Tais atividades estiveram pautadas pela concepção da Divulgação Científica e da Educação Patrimonial, objetivando a aproximação da produção do conhecimento arqueológico com o público local, colocando como ferramentas de formação cultural, crítica e cidadã. Como previsto, foi atendido um amplo e variado público de acadêmicos, funcionários e professores da Universidade, turmas de estudantes do ensino básico das escolas da região e visitantes externos ocasionais.

PALAVRAS-CHAVE: divulgação científica, educação patrimonial, arqueologia.

\section{ABSTRACT}

We present here the activities developed during the 1st Archaeological Workshop of UNESC, realized in scope of the VII Science and Technology Week, during the days 17 and 21 of October of 2016. In addition to an archaeological exhibition, were realized workshops of replica of archaeological ceramics, rock art, and archaeological excavation. These activities were guided by the conception of Scientific Divulgation and Heritage Education aiming at approximation of production of archaeological knowledge with the local public, being placed as tools of cultural, critical and citizen formation. As we previewed, a wide and varied audience of academics, university officials and teachers were attended, students from regional elementary, occasional external visitors.

KEYWORDS: scientific divulgation, heritage education, archaeology.

\footnotetext{
${ }^{1}$ Mestre pelo Programa de Pós-Graduação em Antropologia da Universidade Federal de Pelotas (PPGAnt/UFPel) Pelotas, RS, Brasil

${ }^{2}$ Graduado em História pela Universidade do Extremo Sul Catarinense (UNESC) Criciúma, SC, Brasil.

${ }^{3}$ Doutoranda em História pela Universidade Federal de Santa Catarina (UFSC). Professora do Curso de Pedagogia da Universidade do Extremo Sul Catarinense (UNESC). Criciúma, SC, Brasil

${ }^{4}$ Doutorando em Arqueologia pela Università degli Studi di Ferrara-UNIFE. Laboratório de Arqueologia Pedro Ignácio Schmitz (LAPIS) Universidade do Extremo Sul Catarinense (UNESC). Criciúma, SC, Brasil

${ }^{5}$ Professor do Programa de Pós-Graduação em Ciências Ambientais (PPGCA) Laboratório de Arqueologia Pedro Ignácio Schmitz (LAPIS) Universidade do Extremo Sul Catarinense (UNESC). Criciúma, SC, Brasil - E-mail: jbi@unesc.net,
} 


\section{RESUMEN}

Este artículo presenta las actividades desarrolladas durante el I Taller de Arqueología de la UNESC, realizado en el marco de la VII Semana de Ciencia y Tecnología, durante los días 18 y 21 de octubre de 2016. Además de una exposición arqueológica, se realizaron talleres temáticos de confección de réplicas de cerámica arqueológica, de arte rupestre y de excavación arqueológica. Tales actividades estuvieron pautadas por la concepción de la Divulgación Científica y de la Educación Patrimonial objectivando la aproximación de la producción del conocimiento arqueológico con el público local, colocándose como herramientas que contribuyan a su formación cultural de forma crítica y ciudadana. Se ha atendido un amplio y variado público, desde académicos, funcionarios y profesores de la Universidad hasta clases de estudiantes de enseñanza básica de las escuelas de la región y visitantes externos ocasionales.

PALABRAS CLAVE: divulgación científica, educación patrimonial, arqueología.

\section{INTRODUÇÃO}

Neste artigo, apresentamos as atividades desenvolvidas durante o I Workshop de Arqueologia da UNESC, realizado entre os dias 18 e 20 de outubro de 2016. Tais atividades foram desenvolvidas durante a VII Semana de Ciência e Tecnologia, evento institucional que acontece anualmente em referência à Semana Nacional de Ciência e Tecnologia. No ano de 2016, o evento ocorreu entre os dias 17 e 21 de outubro de 2016 sob a temática "Ciência Alimentando o Brasil". Para a execução deste evento, toda a instituição foi mobilizada com a articulação de distintas instâncias da universidade, que envolveu as diversas Unidades Acadêmicas, cursos, setores, grupos de pesquisas e laboratórios. Foi objetivada a socialização dos conhecimentos produzidos através da pesquisa, ensino e extensão, envolvendo atividades como palestras, minicursos, workshops, oficinas, atrações culturais e apresentações de trabalhos - tanto na modalidade oral quanto pôsteres resultantes principalmente de projetos de pesquisa em iniciação científica e de projetos de extensão e ensino desenvolvidos por alunos e professores da universidade.

Dentro desse escopo, o I Workshop de Arqueologia contribuiu com os objetivos do evento, possibilitando ao público externo e interno da universidade - composto por professores, acadêmicos e funcionários, priorizando, contudo, a participação de professores e alunos das redes pública e privada de ensino da região de atuação da UNESC - espaços de diálogo e interação com o patrimônio arqueológico regional e a produção acadêmica que vem sendo realizada no Projeto de Pesquisas Arqueologia Entre Rios: do Urussanga ao Mampituba (AERUM) (CAMPOS, 2015; CAMPOS et al., 2013; SANTOS; PAVEI; CAMPOS, 2016). 
As atividades estiveram pautadas por duas premissas principais que nortearam sua organização e execução: 1. A preocupação em proporcionar um espaço efetivo de Divulgação Científica que trouxesse ao público, de forma acessível, informações sobre as pesquisas arqueológicas desenvolvidas em âmbito regional e 2. A oferta de um espaço de interação com as instituições de ensino básico, oferecendo subsídios no sentido de contribuir com a formação cultural por meio de uma abordagem lúdica e focada no patrimônio arqueológico regional, inserindo-se em um processo mais amplo das ações de Educação Patrimonial que já vêm sendo executadas na região nos últimos anos (MATIAS et al., 2014; CAMPOS et al., 2015; MOSER; SANTOS; CAMPOS, 2015).

\section{DIVULGAÇÃO CIENTífICA E EDUCAÇÃO PATRIMONIAL: DUAS FACES NA CONSOLIDAÇÃO DO CONHECIMENTO ARQUEOLÓGICO}

Quando falamos em Divulgação Científica, estamos considerando o processo de tornar as informações e resultados que são produzidos no meio científico acessíveis - de forma didática - a um público mais amplo. Há que dizer que as atividades de Divulgação Científica já são realizadas há muito tempo e que tenham surgido "junto com a própria ciência moderna" (SILVA, 2006, p. 54). Por isso:

Já no século XVIII anfiteatros europeus enchiam-se de um público ávido por conhecer novas máquinas e demonstrações de fenômenos pneumáticos, elétricos e mecânicos, apenas para citar alguns exemplos. Algumas exposições e palestras, relacionadas à física, à química ou à medicina, eram itinerantes, percorrendo diversas cidades e, às vezes, diversos países. (SILVA, 2006, p. 54).

Contudo, por tais atividades estarem inseridas em um contexto de incipiente institucionalização da ciência moderna, apresentavam algumas especificidades. Em primeiro lugar, é preciso reconhecer que naquele momento não havia ainda um grupo profissional homogêneo de cientistas (no sentido stricto sensu como é conhecido hoje) e nem um canal específico de transmissão de informações entre pares. Portanto, muitas vezes esses eventos poderiam ser um híbrido entre a divulgação ao grande público e ao mesmo tempo oportunidades nas quais informações científicas seriam transmitidas e apropriadas por uma variedade de profissionais interessados nos resultados das pesquisas. Como aponta Silva (2006, p. 55):

As divisões entre pesquisa científica e popularização, entre pesquisa, formação de profissionais e entretenimento eram muitas vezes praticamente inexistentes. Alguns profissionais, como farmacêuticos, assistiam a aulas privadas, ou seja, proferidas em locais não especificamente voltados para o ensino formal, como as universidades, com o objetivo de aprimorarem seus conhecimentos profissionais em vista 
da então nascente ciência Química. A figura do cientista, do expert ou especialista, detentor de um diploma e de uma pós-graduação que lhe conferem essa posição ainda não existia tal como hoje. (SILVA, 2006, p. $55)$.

Assim, a principal diferença entre esse período inicial da Divulgação Científica e o atual está na ausência de uma orientação explícita em direcionar os resultados obtidos através das pesquisas científicas a um amplo público externo à comunidade acadêmica. Pelo contrário, tais atividades inseriam-se no âmbito da publicização dos trabalhos executados a todos os interessados, fossem cientistas ou não. Esta seria, portanto, uma diferença essencial daquela concepção para a prática atual, que diz respeito, sobretudo, à importância de disponibilizar o conhecimento científico, de forma didática e acessível (tanto do ponto de vista material quanto cognitivo), a um público externo aos habituais círculos de interlocução. Para tanto:

O cientista pode sair do seu lugar "próprio" de interlocução legitimada com outro cientista para produzir interlocuções com outros leitores, não cientistas. Esse lugar é preciso não ser confundido, é preciso ser diferenciado. A expressão "divulgação científica" cumpre esse papel. Instaura uma outra cena, como mostra Authier-Revuz ${ }^{6}$. E isso tem a ver com a produção de diferentes textualizações e, simultaneamente, com o imaginário que produz uma diferenciação e hierarquização de status entre esses diferentes textos em relação ao discurso que veiculam. (SILVA, 2006, p. 58).

Quanto à Educação Patrimonial, embora tenham recentemente se intensificado, com a consolidação de laboratórios e grupos de pesquisas, as iniciativas que envolvem ações educativas junto ao amplo público com foco na preservação do patrimônio cultural são uma demanda que vem sendo explicitada desde os primeiros documentos relativos à preservação do patrimônio em âmbito internacional. Já na Carta de Atenas (Out/1931), destaca-se que "a melhor garantia de conservação de monumentos e obras de arte vem do respeito e do interesse dos próprios povos". A Recomendação de Nova Delhi (Dez/1956), por sua vez, aponta para a necessidade de se "empreender uma ação educativa para despertar e desenvolver o respeito e a estima ao passado". E a Recomendação de Paris Paisagens e Sítios (Dez/1962) salienta o papel das ações junto ao público ao destacar que "[...] uma ação educativa deveria ser empreendida dentro e fora das escolas para despertar e desenvolver o respeito público [...]".

No Brasil, tais práticas têm se multiplicado nos últimos anos, com a incorporação de contribuições proporcionadas por educadores e estudiosos das ciências sociais, gerando um conjunto de diretrizes com o objetivo de propiciar, de forma cada vez mais eficaz, o

${ }^{6}$ AUTHIER-REVUZ, J. A encenação da comunicação no discurso de divulgação científica. In:

Palavras incertas: as não-coincidências do dizer. Campinas, SP: Editora da Unicamp, 1998, p. $\overline{107}$ 131.

() Rev. Arqueologia Pública

Campinas, SP

\begin{tabular}{l|l|l|} 
v.11 & n.2 \\
\hline
\end{tabular}

p. 46

Novembro/2017 1 ISSN 2237-8294 
reconhecimento e a apropriação dos bens culturais. No que se refere à Educação Patrimonial, ainda que o termo tenha sido oficializado no país apenas em 1983, no âmbito do I Seminário sobre o Uso Educacional de Museus e Monumentos, realizado no Museu Imperial de Petrópolis-RJ - onde se discutiu o papel educativo dos museus -, as "práticas educativas" já ocorriam desde a criação do Serviço do Patrimônio Histórico e Artístico Nacional (SPHAN) (BAIMA; BIONDO; NITO, 2015). É nesse evento, contudo, que aparece pela primeira vez o termo "Educação Patrimonial", como um método específico para a atividade educativa centrada nos recursos culturais (HORTA, 2008).

Assim, a partir de tal entendimento, a Educação Patrimonial é concebida como um método educativo que atua tanto no ensino formal quanto no informal, sendo considerada, ainda, um instrumento de "alfabetização cultural", no sentido elencado por Grunberg (2008, p. 39), qual seja:

[Um instrumento] que permite ao cidadão fazer a leitura do mundo que o rodeia e compreender a sociedade e o momento histórico nos quais está inserido. [...] A habilidade de interpretar os objetos e fenômenos culturais amplia a capacidade de compreensão do mundo. Cada produto da criação humana, seja utilitário ou simbólico, é portador de significados e sentidos que devem ser lidos e decodificados através de sua forma, conteúdo e expressão. (GRUNBERG, 2008, p. 39).

Seguindo o paradigma cognitivo proposto por Vygotsky (1998 apud IPHAN, 2014), segundo o qual as ações das pessoas mudam o mundo e elas mesmas, numa dinâmica em que o aprendizado acontece a partir de elementos e processos de mediação, considerando os diferentes contextos culturais e sua atuação na formação cultural dos indivíduos, o IPHAN propõe que as atividades de Educação Patrimonial sejam concebidas como processo de construção mediado, pois compreendem que

[...] tudo é aprendido por meio dos pares que convivem nesses contextos. Dessa maneira, não somente práticas sociais e artefatos são apropriados, mas também os problemas e as situações para os quais eles foram criados. Assim, a mediação pode ser entendida como um processo de desenvolvimento e de aprendizagem humana, como incorporação da cultura, como domínio de modos culturais de agir e pensar, de se relacionar com outros e consigo mesmo. (IPHAN, 2014, p. 22).

Desse modo, admitindo que a memória e o esquecimento são produtos sociais, o IPHAN propõe que essas mediações se coloquem também como instrumentos políticos que busquem a promoção e a manutenção da diversidade sociocultural no sentido de contribuir para que uma pluralidade de referências culturais seja preservada. E qual seria, então, a contribuição da arqueologia neste processo?

Almeida (2008, p. 58) nos indica um bom caminho para se responder tal questão, ao destacar que: 
A arqueologia é um instrumento duplamente importante para a educação. Em primeiro lugar, porque, ao tratar de questões que implicam o estudo de diferentes culturas através da cultura material, permite aos alunos 0 reconhecimento de sua própria identidade cultural. Em segundo lugar, como disciplina científica, a arqueologia pode contribuir para despertar o interesse dos alunos pela ciência de uma maneira geral, o que, na nossa visão, é um ponto fundamental para o desenvolvimento de um espírito crítico em relação à realidade. (ALMEIDA, 2008, p. 58).

Além do mais, vale explorar a ideia dos registros arqueológicos como a lembrança pulsante do fato que o ambiente no qual a sociedade atual se encontra não é dado de forma orgânica, mas é resultado de um processo histórico, remetendo potencialmente à diversidade dos grupos humanos que o habitaram, colocando em relevo, a partir daí, outras ontologias. Esse tipo de raciocínio permitiria pensar, junto à comunidade, uma noção de patrimônio que não fique engessada no tempo ou em uma memória distante e alhures, mas que seja parte do cotidiano e da dinâmica social da comunidade, e que ela assim o sinta, reconheça e se aproprie. Pensa-se, dessa forma, em um patrimônio plural e diverso que se faz presente, ainda que remeta a um passado. É a Arqueologia, por meio das pesquisas, da construção e divulgação de novos conhecimentos, que possibilita iluminar práticas, povos, contextos e temporalidades que nos unem a um passado, e este, por sua vez, reverbera no presente a sua materialidade e o nosso compromisso com a sua manutenção.

\section{REGISTRANDO NOSSO TRAJETO: AÇÕES DO I WORKSHOP DE ARQUEOLOGIA DA UNESC}

Partindo das premissas acima expostas, o I Workshop de Arqueologia da UNESC foi organizado em dois blocos concomitantes: um voltado às visitas ocasionais, que atendeu ao público de forma mais ampla e heterogênea através da exposição "Ocupação Pré-histórica do Extremo Sul Catarinense: 4.000 anos de história", e outro voltado especificamente aos alunos e professores da comunidade escolar regional, por meio da oferta de oficinas temáticas de arqueologia.

Tabela 1: Atividades ofertadas no I Workshop de Arqueologia da UNESC.

\section{Exposição \\ Ocupação Pré-Histórica do Extremo Sul Catarinense: 4.000 anos de história}

Exposição da cultura material das populações pré-coloniais que habitaram o Extremo Sul Catarinense desde há 4.000 anos até a chegada dos colonizadores. Composta por artefatos associados aos grupos sambaquieiros, caçadores-coletores e ceramistas horticultores.

\section{Oficinas Temáticas}


Revista de Arqueologia Pública

\begin{tabular}{|c|l|}
\hline $\begin{array}{c}\text { Confecção de cerâmica } \\
\text { arqueológica }\end{array}$ & $\begin{array}{l}\text { Contato com a matéria-prima (argila) e com a técnica } \\
\text { de confecção de vasilhames cerâmicos própria das } \\
\text { populações ceramistas que viveram no litoral sul } \\
\text { catarinense. }\end{array}$ \\
\hline \multirow{2}{*}{$\begin{array}{c}\text { Arte Rupestre } \\
\text { Atividade que visou demonstrar aos alunos como as } \\
\text { populações antigas utilizavam os recursos existentes } \\
\text { na natureza para confeccionar instrumentos e } \\
\text { pigmentos para a realização de pinturas, tanto em } \\
\text { suportes rochosos quanto em seus próprios corpos, } \\
\text { ampliando as percepções sobre essa dinâmica } \\
\text { específica dentro do âmbito cultural dessas } \\
\text { populações. }\end{array}$} \\
\hline simulada & $\begin{array}{l}\text { Participação dos alunos em uma escavação } \\
\text { arqueológica simulada, na qual puderam ter contato, } \\
\text { de forma prática e lúdica, com noções e técnicas de } \\
\text { parte do cotidiano da pesquisa arqueológica em } \\
\text { campo. }\end{array}$ \\
\hline
\end{tabular}

Fonte: Os autores, 2016.

Com o objetivo de alcançar a comunidade em sua mais ampla variedade, a divulgação desse evento foi realizada através dos vários meios disponíveis. Em um momento inicial, a fim de organizar as diversas informações em um mesmo local de fácil acesso a uma grande parte da comunidade, tanto acadêmica quanto externa à universidade, procedemos à elaboração de um website do workshop contendo a apresentação deste, apontando seu público-alvo e as atividades ofertadas, os procedimentos de inscrição, a comissão organizadora, os realizadores e as informações para contato.

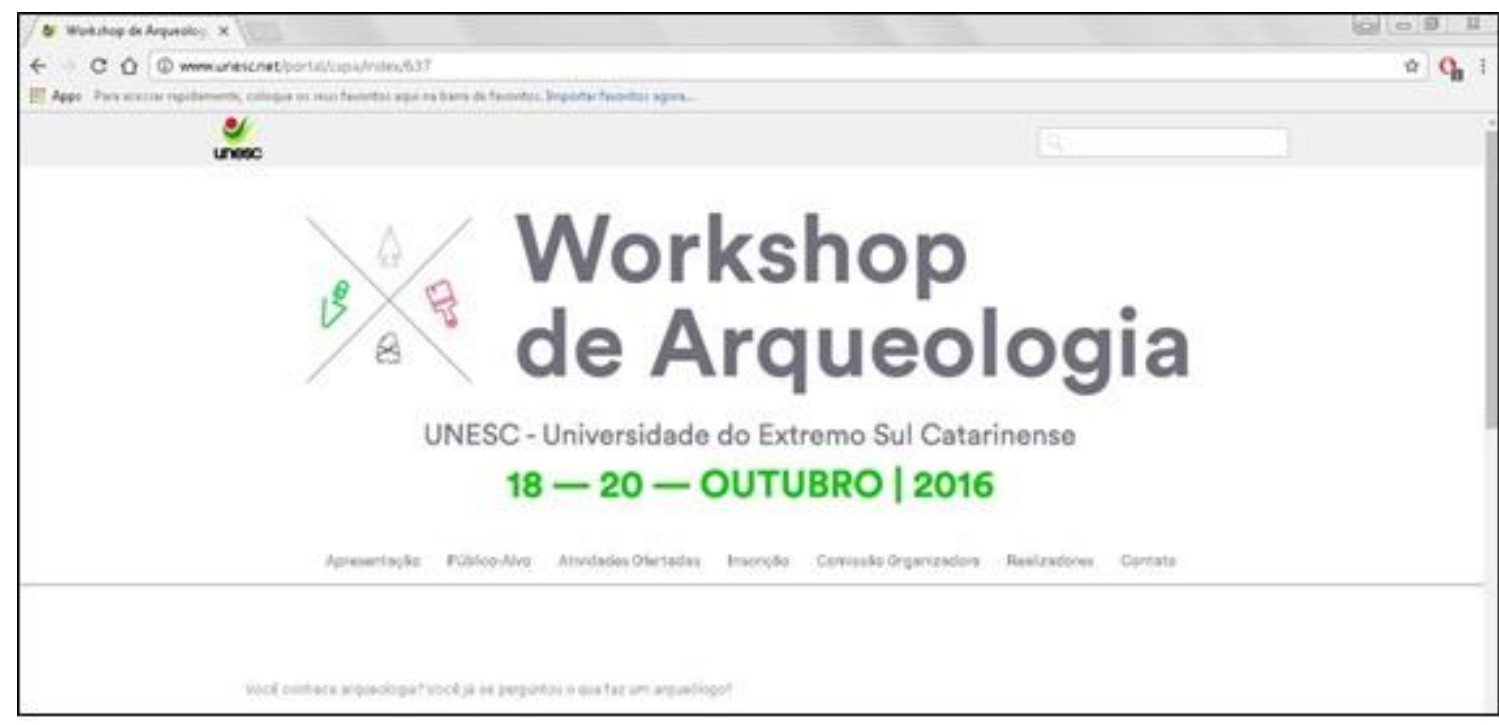

Figura 1: Página inicial do website do I Workshop de Arqueologia da UNESC.

Fonte: Os autores, 2016. 
Elaborados o website e o material de divulgação, o evento começou a ser divulgado também pelas mídias sociais, tendo em vista o amplo e imediato alcance destas ferramentas de comunicação.

Contudo, buscando alcançar de modo direto o público-alvo das oficinas, foram realizadas visitas de divulgação do evento em um grande número de escolas das redes de ensino público e privado dos municípios da região. Nestas visitas eram apresentadas as atividades que seriam desenvolvidas no evento, informando ao mesmo tempo os dias e horários em que elas seriam ofertadas e disponibilizando o contato da equipe para a efetivação da inscrição das respectivas turmas.

Por fim, a imprensa local também foi envolvida tanto na etapa de divulgação quanto durante o evento. Assim, antes mesmo do evento ocorrer, a equipe organizadora participou de entrevistas em emissoras de rádio da região, oportunidades nas quais além da divulgação, aproveitou-se para apresentar algumas noções básicas sobre a arqueologia e a pré-história regional. Durante o evento, ainda, o workshop recebeu a visita da imprensa local (sites de notícias, jornais impressos e TV), oportunidade em que se pôde veicular para a comunidade a realização das atividades, também aproveitando o momento para divulgar as pesquisas arqueológicas efetuadas em âmbito regional.

É importante ressaltar que as oficinas foram organizadas de maneira que todos os alunos de cada turma agendada pudessem participam concomitantemente de todas as atividades ofertadas. Assim, organizaram-se os espaços da oficina de réplica de cerâmica arqueológica, da oficina de arte rupestre e da oficina de escavação arqueológica. Cada um destes espaços foi regido por monitores da equipe, que orientavam as turmas e davam o direcionamento das atividades.

A participação das escolas foi organizada de modo a cumprir um circuito de visitação. Assim, em um primeiro momento, as turmas eram recebidas por um monitor que explicava como a dinâmica do workshop ocorreria e realizava uma apresentação panorâmica do espaço das atividades. Em seguida, os alunos foram encaminhados à exposição "Ocupação Pré-Histórica do Extremo Sul Catarinense: 4.000 anos de história", onde através da mediação foram explanadas algumas noções sobre a ocupação préhistórica regional, lançando mão do acervo exposto, envolvendo-os, assim, para que sua curiosidade fosse aguçada e, dessa forma, também eles se tornando sujeitos de suas aprendizagens. 

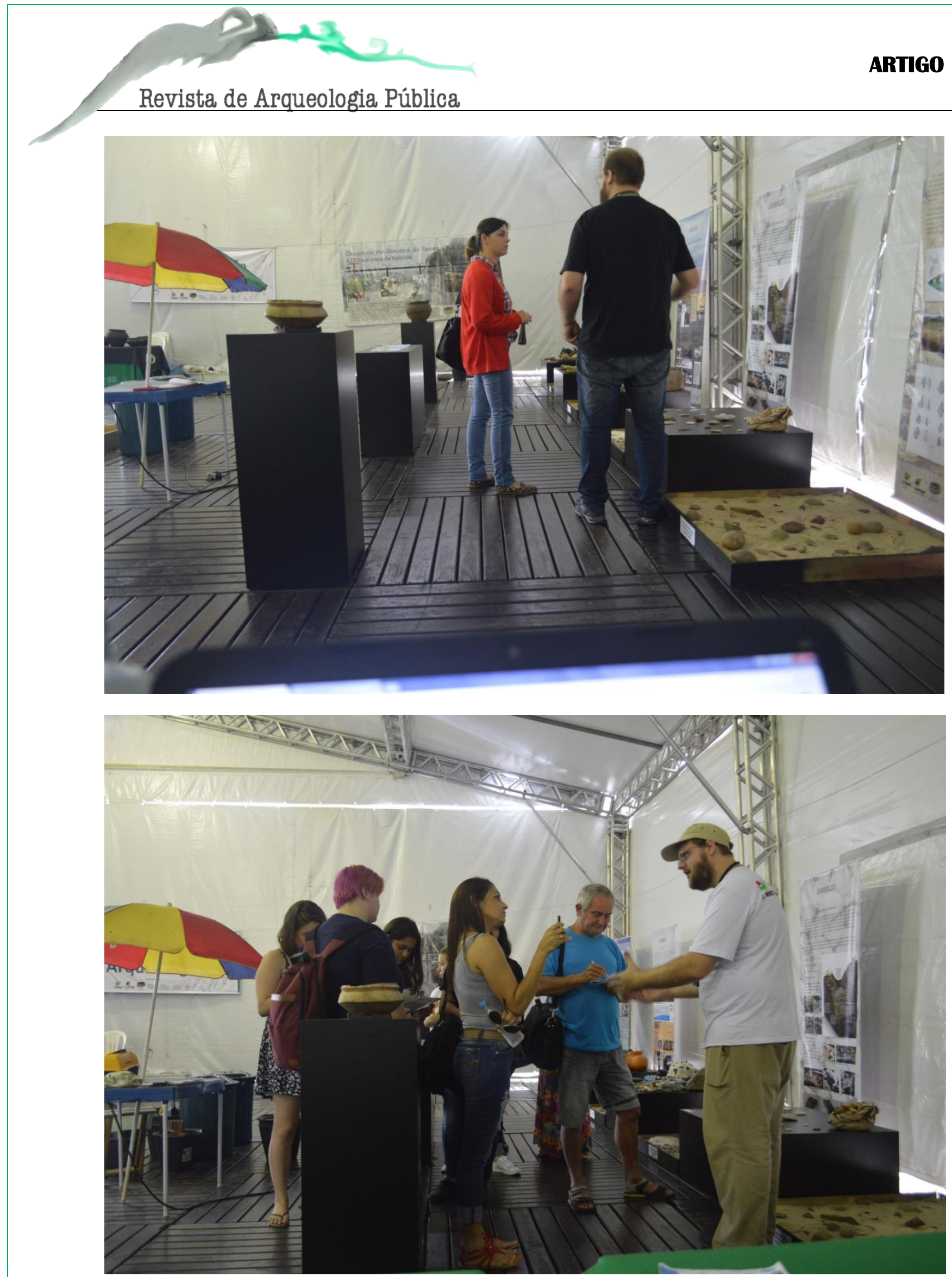

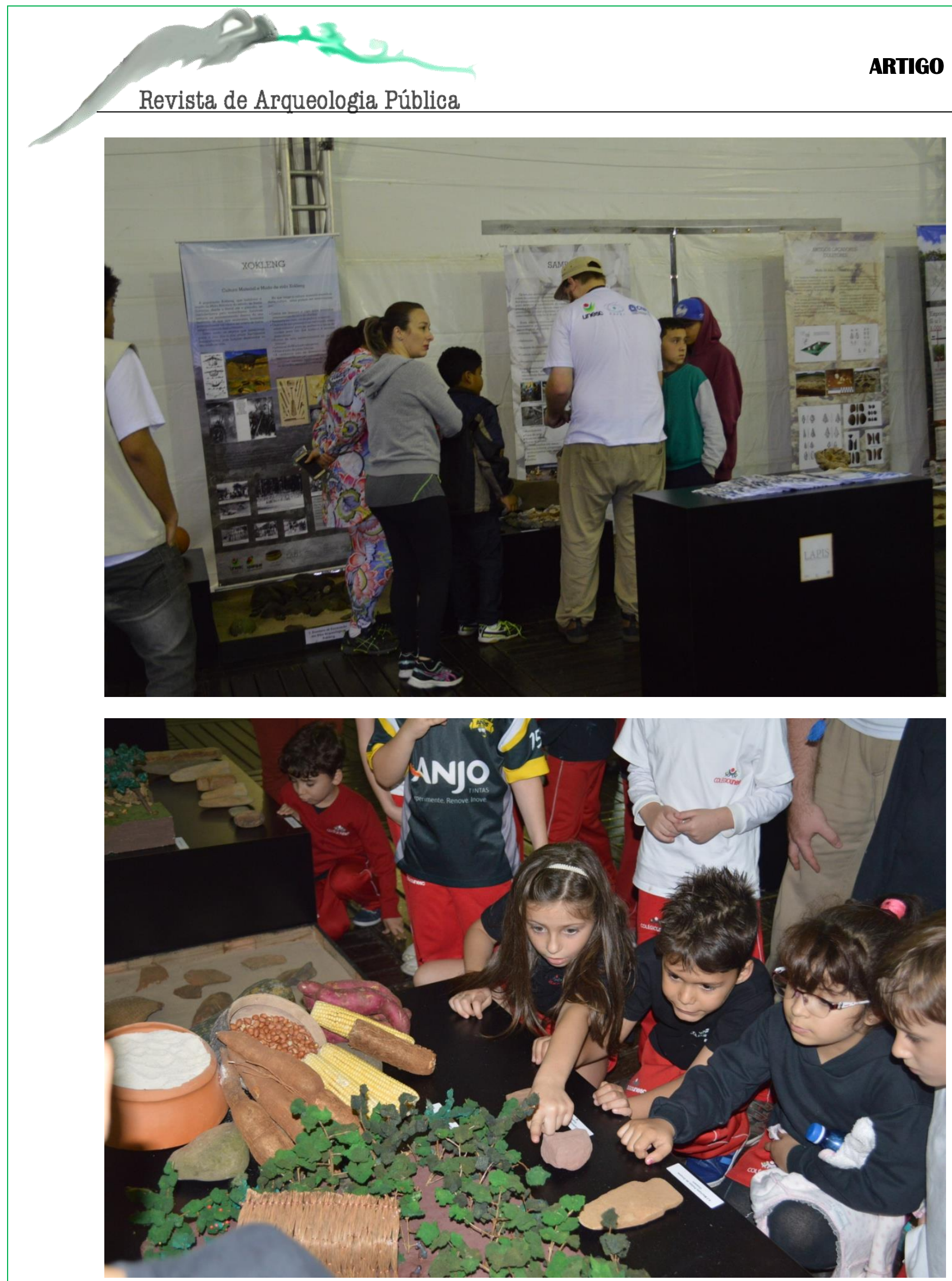

Figuras 2: Exposição Ocupação Pré-Histórica do Extremo Sul Catarinense: 4.000 anos de história. Acima: visitação ocasional do público em geral; abaixo: visitação guiada de alunos do ensino básico. Fonte: Os autores, 2016. 


\section{Revista de Arqueologia Pública}

Após este momento inicial, as turmas foram divididas em três grupos menores e encaminhadas para as oficinas, onde cada grupo de monitores já aguardava para iniciar a mediação nas atividades previstas.

A oficina de réplica de cerâmica arqueológica contou com a colaboração de uma artista plástica e ceramista local. Esta artista, egressa do curso de Artes Visuais da UNESC, já possui histórico de colaboração junto ao Setor de Arqueologia, tendo desenvolvido projeto de estágio sob a temática do processo de manufatura de vasilhames cerâmicos associados às populações Guarani. Dessa maneira, seu know-how veio a contribuir sobremaneira para o desenvolvimento de tais atividades, a partir do conhecimento das técnicas e da gestualidade implicada na confecção dos materiais referidos. $O$ foco desta oficina esteve, sobretudo, na manipulação da argila (adquirida de artesão local e previamente processada) e na técnica de manufatura dos vasilhames. Pela limitação do tempo e a faixa etária dos alunos, os monitores focavam sua apresentação na forma como os roletes deveriam ser confeccionados e em sua técnica de sobreposição para a construção dos vasilhames. A partir de uma explanação inicial, portanto, os participantes da oficina eram instigados a "colocarem a mão na massa", iniciando a confecção de suas próprias vasilhas. Ao mesmo tempo, outros vasilhames eram confeccionados pela artesã, que serviam como auxílio visual e inspiração para que os alunos participassem da atividade.

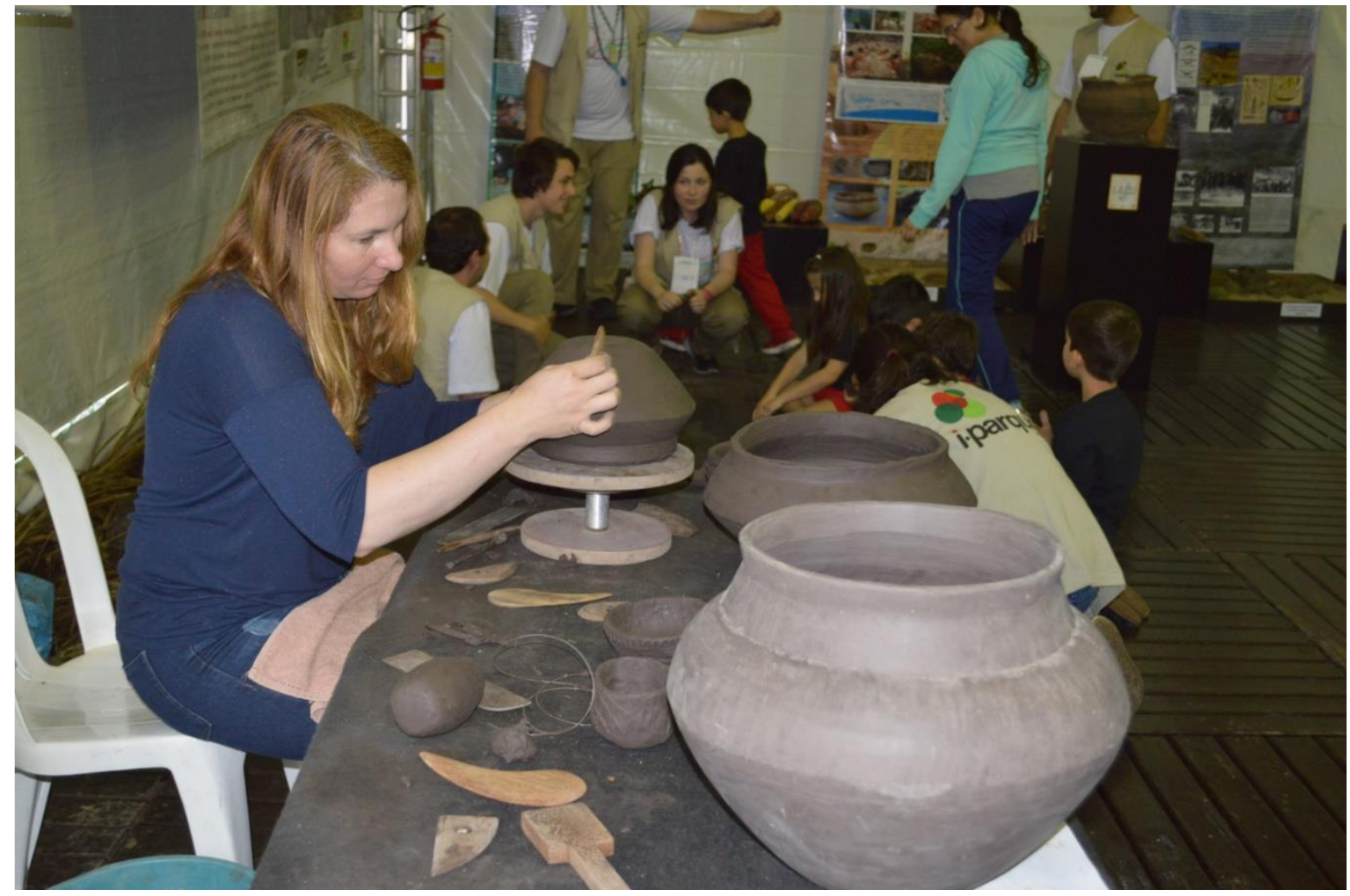



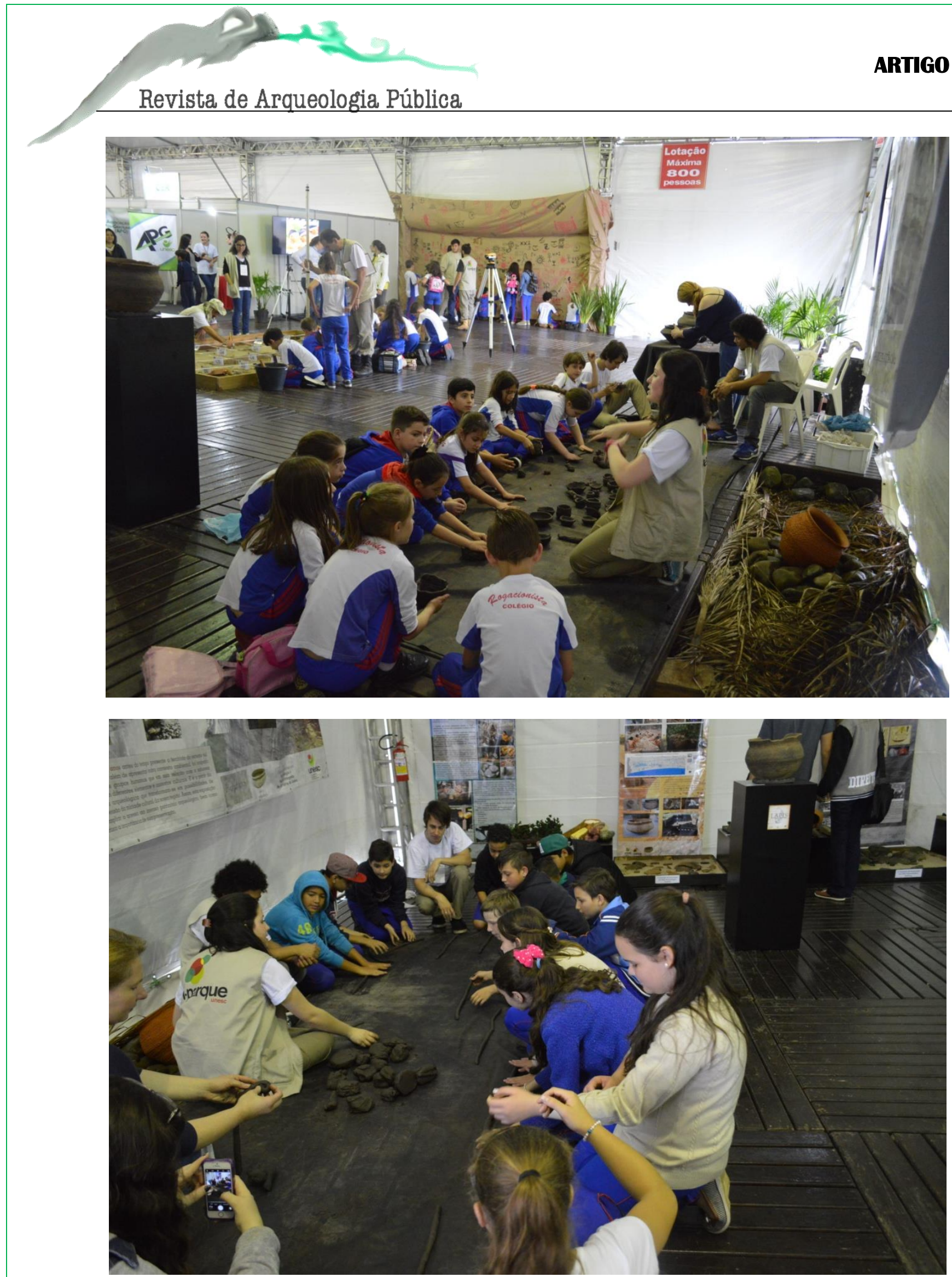


\section{Revista de Arqueologia Pública}

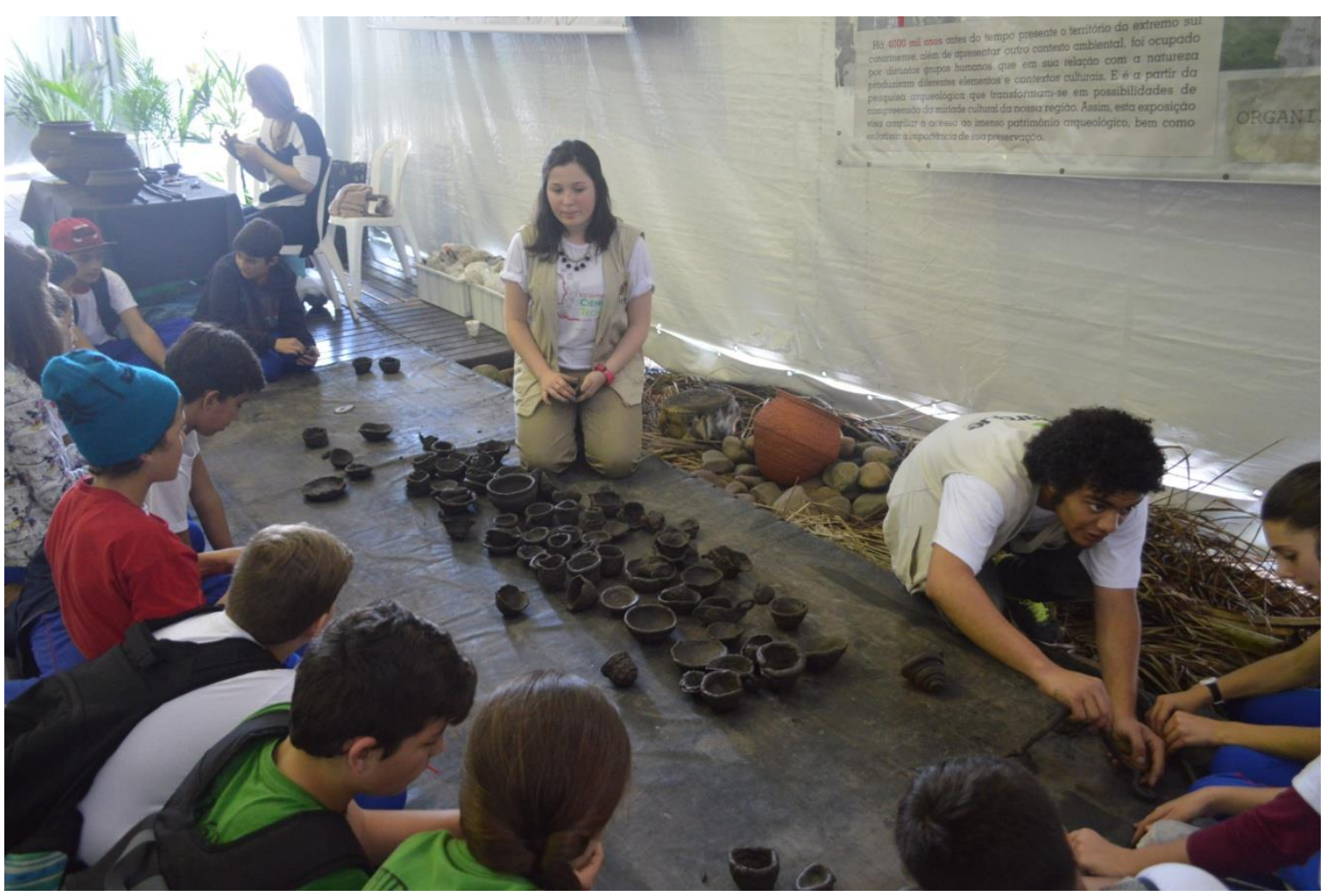

Figuras 3: Oficina de confecção de réplicas de cerâmica arqueológica. Acima e à esquerda: artesã confeccionando réplicas de cerâmica tradicional das populações Guarani; demais imagens: alunos do ensino básico participando das atividades de confecção de cerâmica.

Fonte: Os autores, 2016.

$\mathrm{Na}$ oficina de arte rupestre, a equipe de monitores recebia os alunos realizando, inicialmente, uma breve explanação sobre os materiais e técnicas utilizadas no contexto pré-histórico tanto para a realização de gravuras quanto de pinturas. Assim, era explicado como se dava a obtenção dos diferentes tipos de matérias-primas, instrumentos líticos, até pincéis elaborados a partir de fibra vegetal e filamento animal. Demonstrava-se, ainda, a matéria-prima e a forma de obtenção dos pigmentos. Após esta demonstração introdutória, os ouvintes eram estimulados a pintarem um painel que compunha o espaço dessa oficina. 


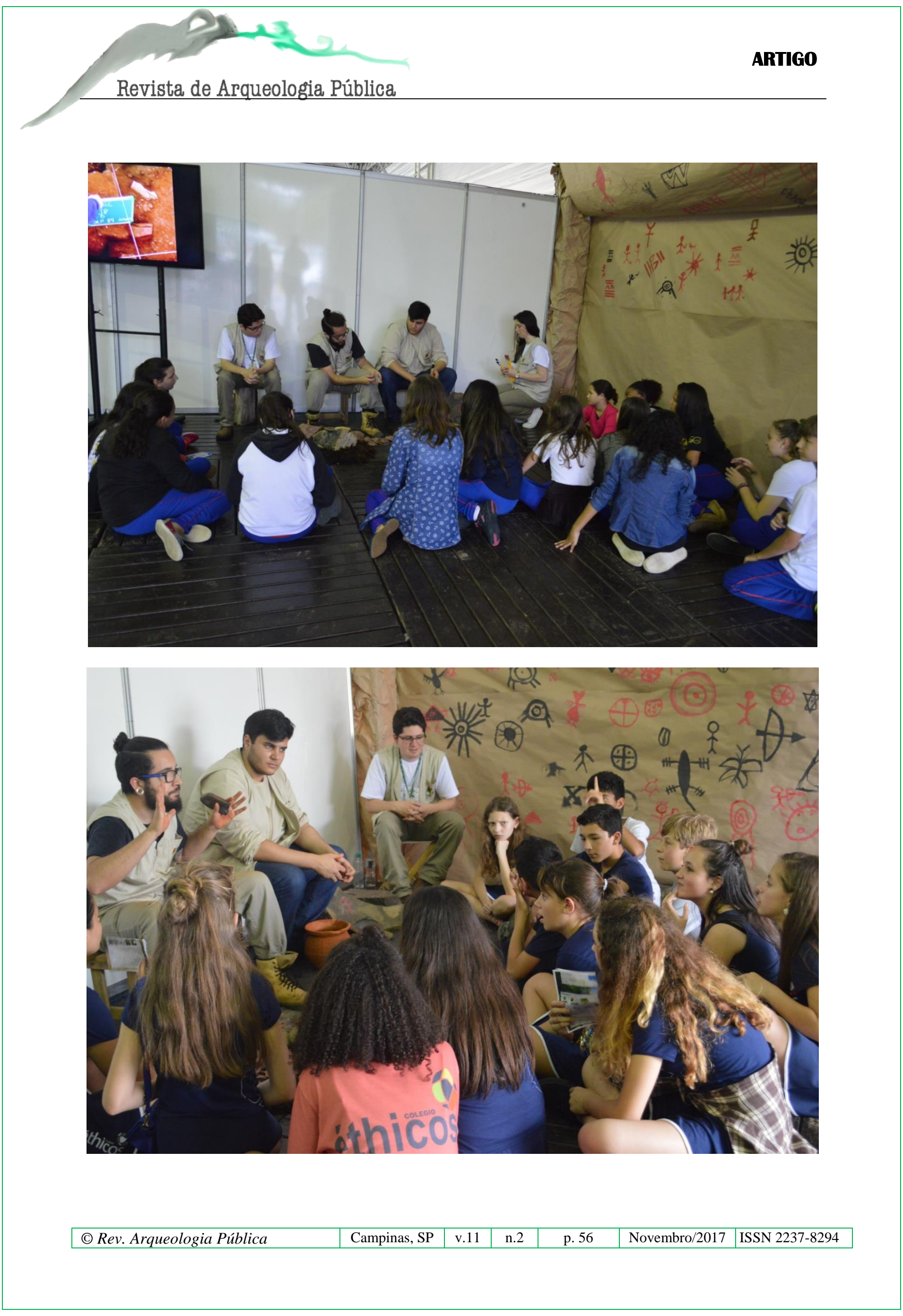



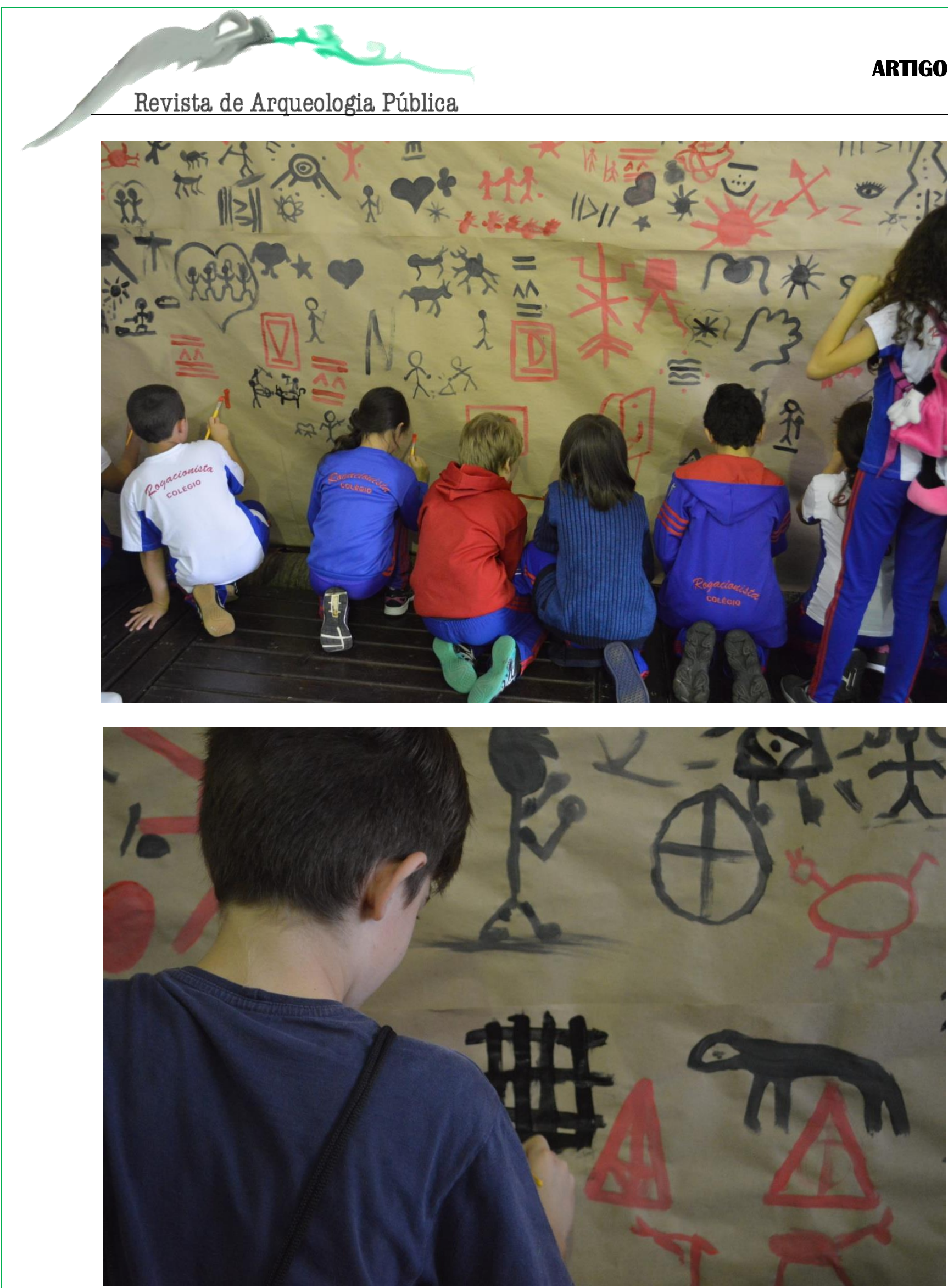

Figuras 4: Oficina de arte rupestre. Acima: monitor explanando sobre a confecção de instrumentos e as técnicas que envolvem a confecção de arte rupestre. Abaixo: alunos do ensino básico participando das atividades de pintura no mural. Fonte: Os autores, 2016. 
Revista de Arqueologia Pública

Por fim, a oficina de escavação arqueológica buscou colocar os participantes em contato com noções práticas do cotidiano do arqueólogo no trabalho de escavação. Para atingir tal objetivo, foi previamente montado um sítio arqueológico artificial de $9 \mathrm{~m}^{2}$, com espessura de $50 \mathrm{~cm}$. Para a montagem do sítio, foram utilizadas réplicas de materiais arqueológicos. Estes materiais foram dispostos estrategicamente de forma a cobrir todas as quadrículas. Também orientados por monitores, os alunos participantes eram divididos em duplas, e cada uma destas ficava a cargo de escavar uma quadrícula previamente delimitada.

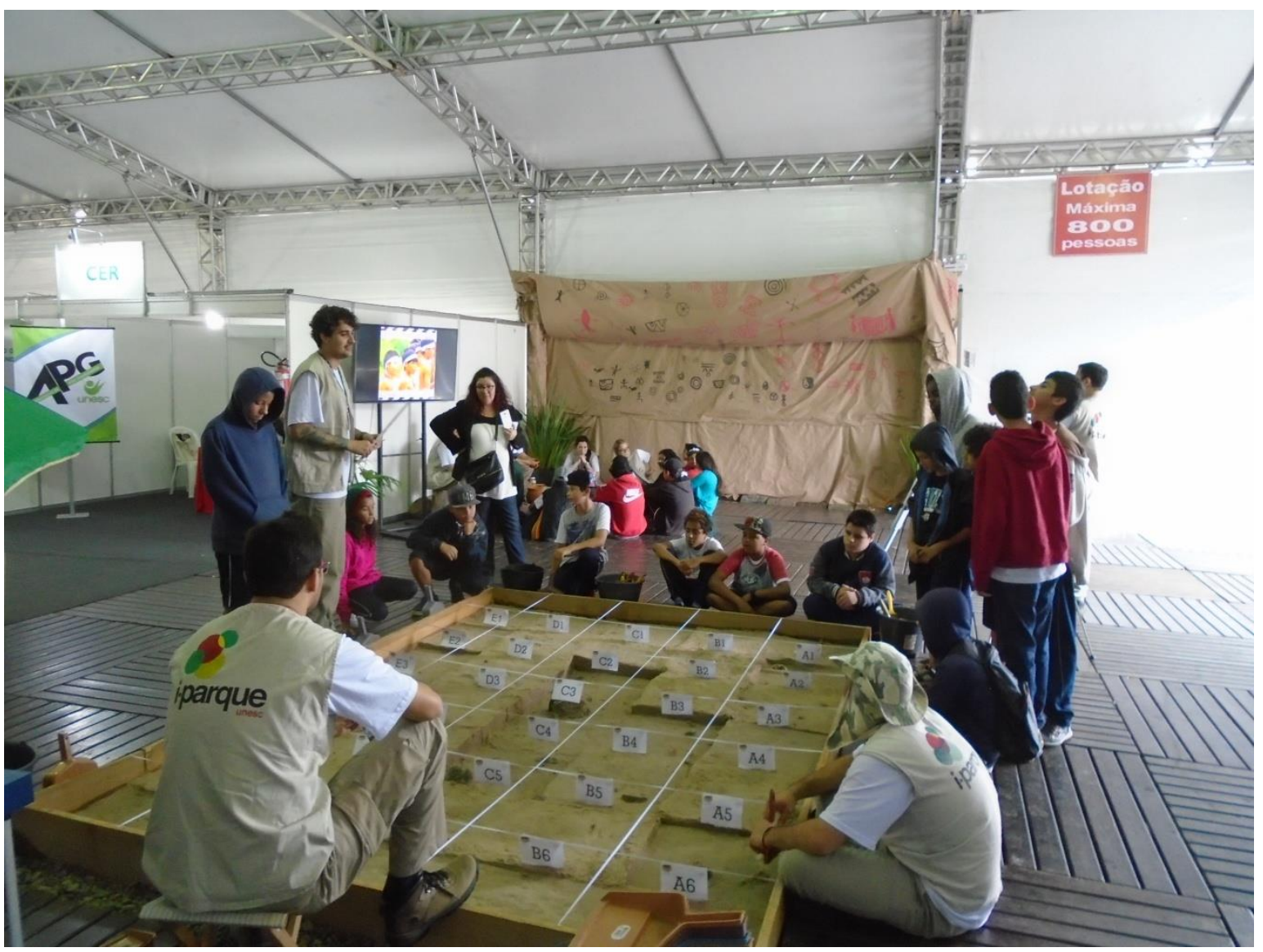



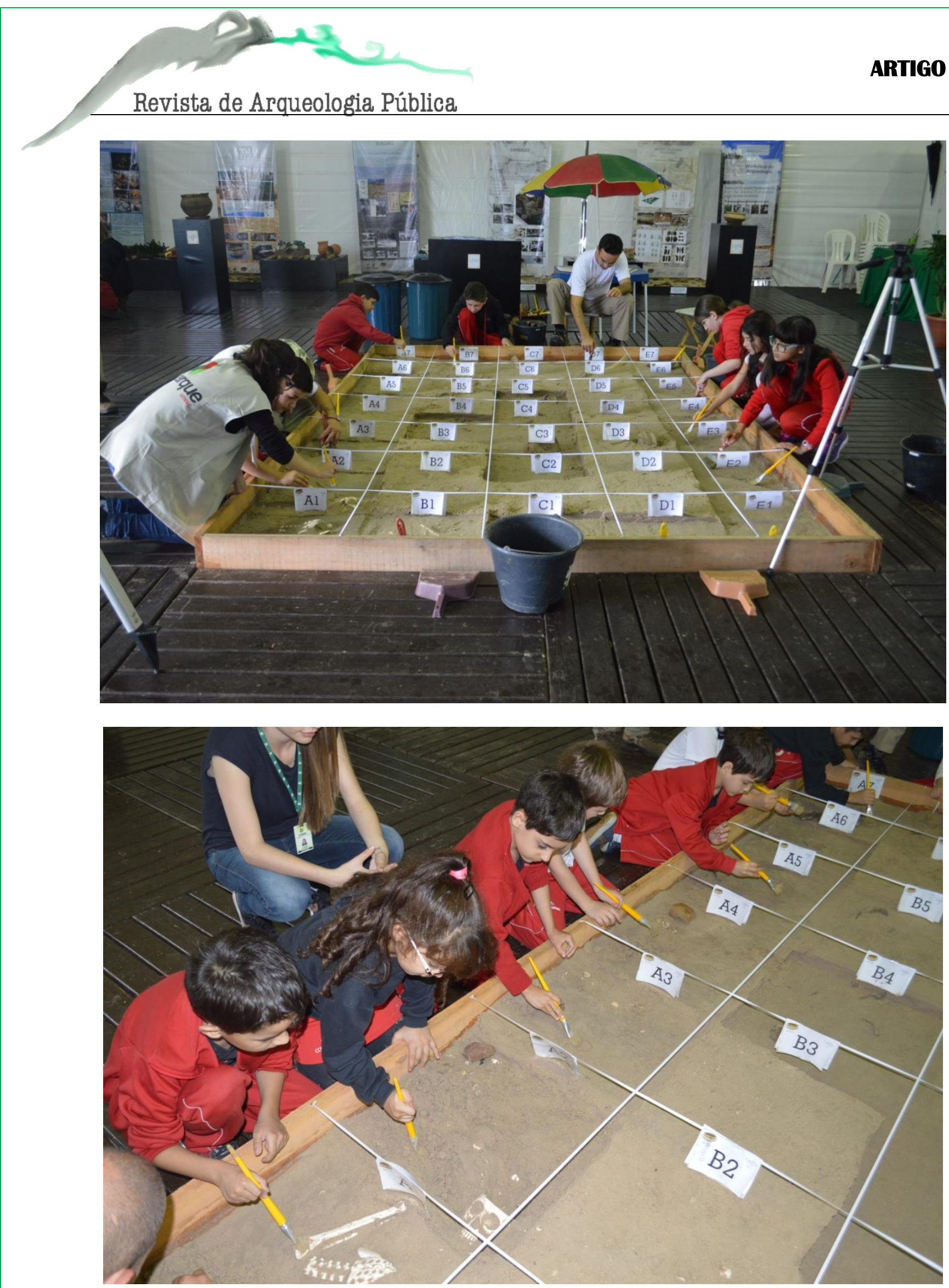


\section{Revista de Arqueologia Pública}

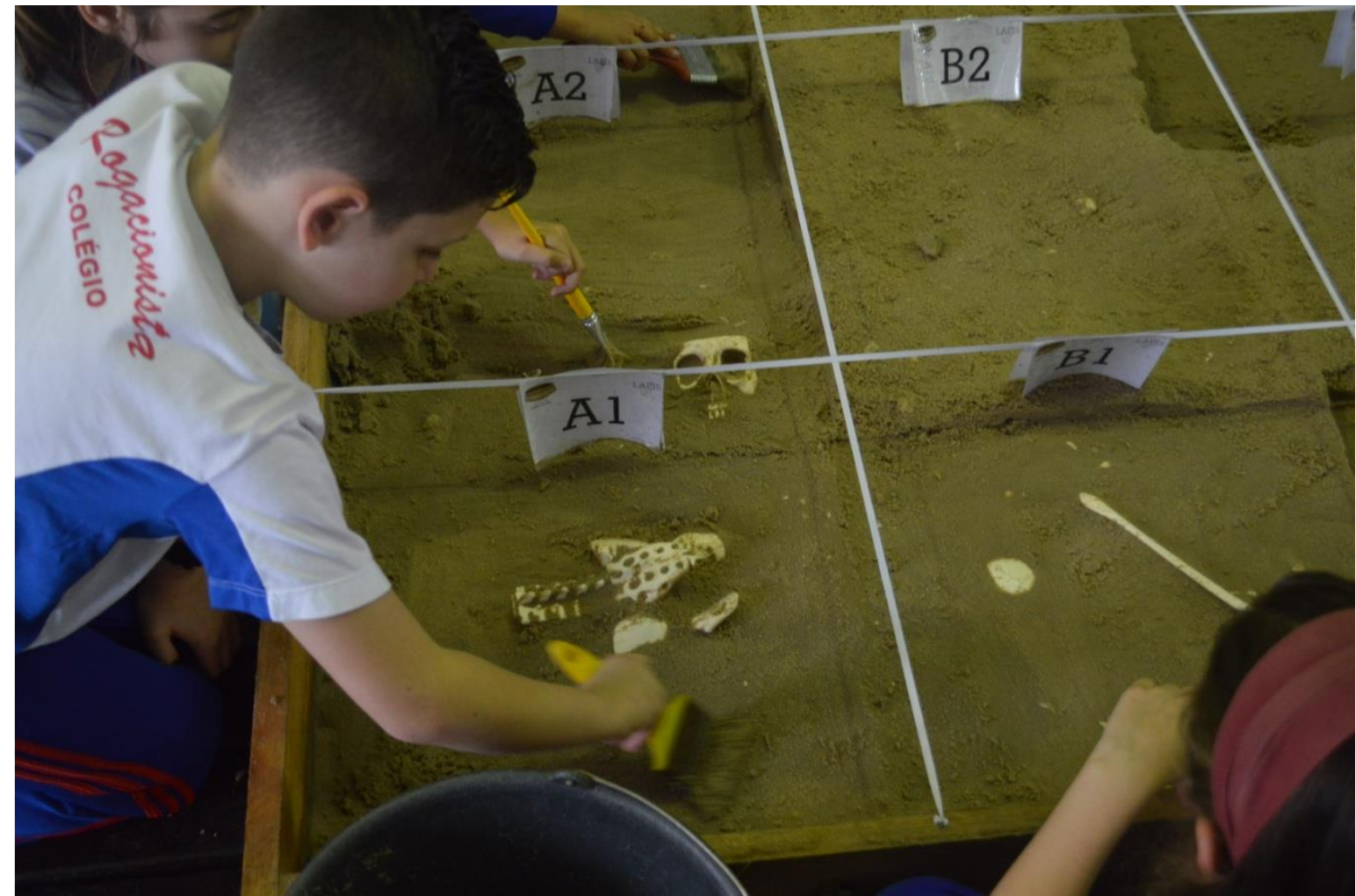

Figuras 5: Oficina de escavação arqueológica. Acima e à esquerda: monitor recepcionando os alunos e apresentando a oficina. Imagens restantes: alunos participando das atividades de escavação. Fonte: Os autores, 2016.

Ao todo, o evento recebeu a visita tanto na exposição quanto nas oficinas de um amplo público constituído de vários setores da comunidade local, acadêmica e não acadêmica. Da rede de educação regional, passaram pelo evento aproximadamente 800 alunos, envolvendo turmas do ensino fundamental até o ensino médio. O público alcançado, portanto, abrangeu várias faixas etárias, desde crianças dos primeiros anos do ensino fundamental até universitários e funcionários da universidade, que tiveram a oportunidade de entrar em contato com o vasto universo arqueológico, bem como se debruçarem sobre saberes e fazeres de povos que habitaram a região e que fazem parte do patrimônio arqueológico.

\section{CONSIDERAÇÕES FINAIS}

As etapas de planejamento, organização e desenvolvimento do workshop proporcionaram um amplo leque de possibilidades quanto à divulgação das pesquisas arqueológicas efetuadas em âmbito regional e à colaboração com as escolas no que diz respeito à formação crítica dos alunos (CAMPOS et al., 2016). Já desde os primeiros momentos do planejamento, as estratégias de divulgação do evento objetivaram um 
alcance múltiplo do público, em que os espaços puderam ser aproveitados da melhor maneira para a divulgação do conhecimento arqueológico. Assim, a participação de pesquisadores da equipe em programas de rádio de cunho regional foi vista como uma oportunidade não só de divulgar o workshop de forma restrita, mas de delinear algumas questões acerca da prática da arqueologia, aproximando-a do público tanto do ponto de vista espacial quanto epistêmico. Assim, o discurso predominante em nossas entradas em tais programas esteve voltado para o esforço de desmistificar a prática da arqueologia como empreendimento aventureiro e caracterizado essencialmente por descobertas fortuitas de objetos raros (tal como fazem crer a imagem de um Indiana Jones ou uma Lara Croft), ou seja, salientávamos seu caráter profissional, metódico e sistemático, apontando-a como um importante campo de estudos científicos que contribuem para o entendimento da formação histórica e cultural regional e também para demonstrar as diversas manifestações do comportamento humano em sociedade, nas mais distintas épocas. Aliado a isso, evidenciávamos as pesquisas que estão sendo efetuadas em âmbito local, demonstrando a diversidade cultural das populações que ali viveram e alargando o período de ocupações destes ambientes para além daquele preconizado pela história regional tradicional e enraizada no senso comum, para a qual o passado digno de ser lembrado limita-se temporalmente ao estabelecimento dos colonizadores europeus a partir, sobretudo, do século XIX.

A divulgação nas escolas, por sua vez, contribuiu para dar continuidade à aproximação que já vem sendo fomentada entre as pesquisas realizadas no âmbito do Projeto de Arqueologia Entre Rios, da Universidade do Extremo Sul Catarinense, com as instituições de ensino regular dos municípios da região. Com efeito, Campos et al. (2016) ressaltam a importância desta articulação, haja vista o papel de tais instituições na formação cultural de seus alunos. "Acredita-se assim na grande importância do papel da escola na socialização do conhecimento; este que, quando sincero e objetivo, contribui para levar os resultados da pesquisa arqueológica até a sociedade" (CAMPOS et al., 2016, p. 106).

Nesse sentido, a exposição "Ocupação Pré-Histórica do Extremo Sul Catarinense: 4.000 anos de história" foi montada de uma forma a explanar, de modo didático, a cronologia da ocupação pré-histórica regional a partir de suas mais diversas manifestações materiais desde o período mais remoto, representado pelos caçadores-coletores da Mata Atlântica até a ocupação ceramista no litoral há cerca de 600 anos associadas às populações Guarani (SANTOS; PAVEI; CAMPOS, 2016). Isso permitiu aos visitantes o contato com a variedade da cultura material do contexto arqueológico regional, 
possibilitando ampliar a noção temporal da presença humana nestes ambientes e sua diversidade cultural. Indo, portanto, ao encontro do que advoga Grunberg (2007, p. 4), ao colocar que:

O Brasil é um país pluricultural, isso significa que existem diversas formas e expressões de interpretar e se relacionar com o mundo. Reconhecer que todos os povos produzem cultura e que cada um tem uma forma diferente de se expressar é aceitar a diversidade cultural e reconhecer também que não existem culturas superiores a outras. (GRUNBERG, 2007, p. 4).

Dessa forma, a noção de Educação Patrimonial que pautou as atividades foi entendida como uma metodologia na qual o patrimônio arqueológico é utilizado como instrumento pedagógico para a formação crítica e cidadã, por meio do incentivo ao reconhecimento da diversidade (social, cultural e temporal) e à tomada de consciência de si e de sua comunidade dentro de um processo de formação histórica da sociedade e do ambiente na qual os alunos estão inseridos (GRUNBERG, 2008; HORTA, 2008). Portanto, assim como a função do ensino de história, geografia, biologia (e das demais disciplinas) na rede básica de ensino não é a de formar profissionais historiadores, geógrafos, biólogos (e demais profissionais), mas de utilizar o conhecimento inerente a cada área como ferramenta para o desenvolvimento de competências e habilidades na formação do aluno, entende-se também que a função das práticas da Educação Patrimonial voltada para a arqueologia não é a de formar peritos no estudo da cultura material, mas a de contribuir para o desenvolvimento de competências e habilidades junto ao público abrangido, contribuindo para sua formação cultural.

Nesse sentido, as oficinas, em suas especificidades, proporcionaram que 0 patrimônio arqueológico e a prática da arqueologia pudessem ser desvelados ao público a partir de diferentes estratégias, dentre as quais se podem elencar:

1. Oficina de confecção de cerâmica arqueológica: a proposição, de certa forma, de uma "arqueologia reversa", onde se partiu da confecção dos vasilhames, focando em sua técnica, a fim de abordar os vestígios arqueológicos relacionados a tais materiais.

2. Oficina de arte rupestre: reconhecimento da "cultura do outro", de que "o outro também possui cultura", com seus mecanismos, elementos e dinâmicas próprias; e que para a manutenção de tais expressões culturais é mantido um sofisticado aparato tecnológico e cognitivo.

3. Oficina de escavação arqueológica: desmitificar a prática arqueológica como aventureira e descobridora de raridades, demonstrando que para a geração do conhecimento arqueológico, é aplicada toda uma série de técnicas e instrumentos.

Dentro da lógica de interação entre a pesquisa arqueológica e as instituições de ensino, tendo, neste caso, como principal interface as oficinas temáticas oferecidas,

\begin{tabular}{|l|l|l|l|l|l|l|}
\hline (c) Rev. Arqueologia Pública & Campinas, SP & v.11 & n.2 & p. 62 & Novembro/2017 & ISSN 2237-8294
\end{tabular}


entendemos que as atividades propostas contribuem com subsídios para se tratarem de várias disciplinas da grade disciplinar das escolas, como geografia (território, ambiente, matéria-prima), artes (arte rupestre, artesanato, desenho técnico), história (trajetória das sociedades ao longo do tempo e do espaço), sociologia (organização social e cultural), matemática (geometria, tabulação de dados), biologia (sepultamentos, vestígios faunísticos e florísticos), química e física (transformação das matérias-primas em artefatos), dentre outras.

Como destaca Almeida (2003, p. 276): "Nosso compromisso profissional passa pelo imperativo de mostrar ao público uma Arqueologia que, longe de ser uma atividade de entretenimento, seja um instrumento na construção de sua memória, de sua história, de sua identidade e de sua cidadania". Ao serem convidados a participar das oficinas, os alunos tiveram a oportunidade de entrar em contato com distintas modalidades materiais que fazem parte do cotidiano da pesquisa arqueológica. Esse contato possibilita, assim, a dessacralização da arqueologia como um empreendimento aventureiro que "descobre" relíquias de civilizações passadas, mostrando que a produção de conhecimento arqueológico resulta de processos cotidianos, a partir da aplicação de técnicas que são pautadas em métodos e orientados por quadros teóricos delimitados. Por outro lado, esse mesmo contato permite mostrar que a prática arqueológica vai além da estática do sítio arqueológico, remetendo a situações diversas de outras culturas e outros tempos, fomentando a criticidade do aluno e sua recepção da diversidade cultural como algo benéfico e enriquecedor tanto do ponto de vista pessoal quanto social.

\section{AGRADECIMENTOS}

Agradecemos a diversos colegas, que contribuíram de diferentes maneiras, para que este projeto fosse um sucesso: Simone Milak, Diego Pavei, Herom Cezaro, Giovana Pereira, Giovana Cadorin, Silvia Aline Pereira Dagostin, Helen Pagani, Cristian Hildebrando, Juliano Gordo Costa, André Ribeiro, Jodoel Cardoso, Alexandre Sachet, Aline da Rocha, Jhenifer Paim, Jean de Farias, Alan de Souza. Mencionamos, ainda, o apoio institucional da Universidade do Extremo Sul Catarinense (UNESC), agradecimento especial a Professora Gisele Silveira Coelho Lopes (Coordenadora da VII SCT da Unesc), e a Professora Reitora Luciane Bisognin Ceretta pelo apoio ao projeto. A responsabilidade pelas ideias restringe-se aos autores. 


\section{REFERÊNCIAS BIBLIOGRÁFICAS}

ALMEIDA, Marcia Bezerra. O Público e o Patrimônio Arqueológico: Reflexões para a Arqueologia Pública no Brasil. Habitus, Goiânia, v. 1, n.1, p. 275-296, 2003.

ALMEIDA, Marcia Bezerra. Arqueologia e Educação. In: BARRETO, Éuder Arrais et al. Patrimônio Cultural e Educação: artigos e resultados. Goiânia: UFG, 2008, p. 57-65.

BAIMA, Carlúcio; BIONDO, Fernanda; NITO, Mariana Kimie. Educação Patrimonial no Campo da Arqueologia: desafios e contribuições. Revista de Arqueologia Pública, Atas da Segunda Semana de Arqueologia - Parte 1, v. 9, n. 3(13), p. 1-11, 2015.

CAMPOS, Juliano Bitencourt. Arqueologia Entre Rios e a Gestão Integrada do Território no Extremo Sul de Santa Catarina - Brasil. Vila Real: Universidade de Trás-os-Montes e Alto Douro, p. 261, 2015. (Tese de Doutorado em Quaternário, Materiais e Cultura) Universidade de Trás-os-Montes e Alto Douro, Portugal, 2015.

CAMPOS, Juliano Bitencourt; SANTOS, Marcos César Pereira; ROSA, Rafael Casagrande da; RICKEN, Claudio; ZOCCHE, Jairo José. Arqueologia Entre Rios: do Urussanga ao Mampituba. Registros arqueológicos pré-históricos no extremo sul catarinense. Cadernos do LEPAARQ, v. 10, n. 20, p. 9-40, 2013.

CAMPOS, Juliano Bitencourt; SANTOS, Marcos Cesar Pereira; PESTANA, Marlon Borges; SANTOS, Josiel dos; MATIAS, Carlos dos Passos Paulo. Patrimônio e Cidadania: A Educação Patrimonial nas escolas e a formação cidadã. Revista Memorare, Tubarão/SC, v. 3, n. 1, p. 95-113, 2016.

CARTA de Atenas (Out/1931). Disponível em: <http://portal.iphan.gov.br/uploads/ckfinder/arquivos/Carta\%20de\%20Atenas\%201933.pdf>. Acesso em: 02 mar. 2017.

GRUNBERG, Evelina. Manual de atividades práticas de Educação Patrimonial. Brasília, DF: IPHAN, 2007.

GRUNBERG, Evelina. Educação Patrimonial: trajetórias. In: BARRETO, Éuder Arrais et al. Patrimônio Cultural e Educação: artigos e resultados. Goiânia: UFG, 2008, p. 37-41.

HORTA, Maria de Lourdes Parreiras. Educação Patrimonial. In: BARRETO, Éuder Arrais et al. Patrimônio Cultural e Educação: artigos e resultados. Goiânia: UFG, 2008, p. 15-21. 


\section{Revista de Arqueologia Pública}

IPHAN, Instituto do Patrimônio Histórico e Artístico Nacional. Educação Patrimonial: histórico, conceitos e processos. IPHAN, 2014.

MATIAS, Carlos dos Passos Paulo; ZOCCHE, Jairo José; SANTOS, Marcos Cesar Pereira; SANTOS, Josiel dos; RONCONI, Richard Vieira; CAMPOS, Juliano Bitencourt. Socialização do Conhecimento: Reflexões Educacionais sobre o Patrimônio Histórico do Extremo Sul Catarinense. In: CAMPOS, Juliano Bitencourt; ZOCCHE, Jairo José; CEREZER, Jedson Francisco; OOSTERBEEK, Luiz Miguel (Org.). Arqueologia Iberoamericana e Transatlântica: Arqueologia, Sociedade e Território. Erechim: Habilis Press, 2014, p. 377388.

MOSER, Diego; SANTOS, Josiel dos; CAMPOS, Juliano Bitencourt. Ações de Educação Patrimonial desenvolvidas pelo Grupo de Pesquisa Arqueologia e Gestão Integrada do Território da Unesc: o caso do Sambaqui da Lagoa dos Freitas - Balneário Rincão/SC. In: I SEMINÁRIO DE EDUCAÇÃO, CONHECIMENTO E PROCESSOS EDUCATIVOS: UNIVERSIDADE, EDUCAÇÃO E SOCIEDADE. 2015. Criciúma, SC. Anais... Criciúma: UNESC, 2015.

RECOMENDAÇÃO de Nova Delhi (Dez/1956). Disponível em: $<$ http://portal.iphan.gov.br/uploads/ckfinder/arquivos/Recomendacao\%20de\%20Nova\%20Dh eli\%201956.pdf>. Acesso em: 02 mar. 2017.

RECOMENDAÇÃO Paris Paisagens e Sítios (Dez/1962). Disponível em: <http://portal.iphan.gov.br/uploads/ckfinder/arquivos/Recomendacao\%20de\%20Paris\%2019 62.pdf>. Acesso em: 02 mar. 2017.

SANTOS, Marcos Cesar Pereira; PAVEI, Diego Dias; CAMPOS, Juliano Bitencourt. Arqueologia Entre Rios: do Urussanga ao Mampituba: paleoambiente, cultura material e ocupação humana na paisagem litorânea do Extremo Sul Catarinense entre 3500-200 anos antes do Presente. Cadernos do CEOM, v. 29, n. 45, p. 64-86, 2016.

SILVA, Henrique César da. O que é Divulgação Científica? Ciência \& Ensino, v. 1, n. 1, p. 53-59, 2006. 